\title{
Photography, Production Design, and Editing
}

\author{
Vicente Sánchez-Biosca
}

\section{An Anomalous Cinema?}

Film historians frequently lament what they insist on seeing as the "exceptionalism" of Spanish cinema. But a comparative study of photography, production design, and editing reveals a substantial measure of normality with respect to styles, techniques, and fashions existing in other national cinema traditions. The specificity of Spanish cinema has to be sought in its periodization and the ways in which such styles, techniques, and fashions were adapted. To discuss all this in detail would mean writing a history of film form in Spain covering more than a century - obviously impossible here. My aim will rather be to highlight some specific modes of stylistic expression through brief analysis of relevant case studies.

It is crucial here to remember that photography, production design, and editing are inseparably linked. While they are different in technical, artistic, and professional terms, analysis of their intersection can offer useful insights into the study of film form. For example, the arcane practice of reconstructing historical paintings in the sets of CIFESA's historical films involved meticulous attention to props and costumes, and also affected the dynamics of editing, since each cut broke the frame's compositional coherence. Additionally, the interiors crammed with detail determined the kind of lighting equipment to be used. By contrast, the exteriors preferred in modern film go together with a preference for more balanced natural light, as well as lightweight cameras and direct cinema.

Nonetheless, recognition of this interconnectedness should not make us forget the relatively autonomous historical trajectory of each of these three processes. 
The importance of art direction dates back to the 1920s, and increased in the 1930s with the construction of film studios - CEA (1932), Orphea Film (1932), Ballesteros (1933), ECESA (1933), Iberia Films (1933) - that would continue to operate over a longer period than in other countries (Gorostiza 1997; see also Chapter 14). As far as editing techniques are concerned, these have been influenced by many factors, from the creativity of the avant-garde to the international style in genre cinema, and also the way of photographing exteriors that dominated the two first decades of studio photography (inspired by painting) until the impact of neo-realism and the New Waves brought about a radical change of sensibility.

The case studies chosen for discussion in this chapter all involve photography, production design, and editing in varying combinations and to different extents. In each case, the analysis seeks to illustrate a moment of stasis or change, highlighting features that permit comparative study: iconography, realism, experimentalism, the sound/image dialectic, the autonomization of design, and the adoption of techniques borrowed from television and the video clip, among other things.

\section{A Cinema of Attractions}

In 1906, a short film entitled El ciego de la aldea / The Village Blind Man was shot in the Valencian village of Godella. Made by the production company Cuesta, its author was the photographer and, from this point on, filmmaker Ángel García Cardona. His figure encapsulated the efforts to endow cinema with an industrial and leisure infrastructure (dedicated cinema theaters, regular production, films with a plotline, etc.) - something that had only existed since the previous year - in a city that was taking a decisive leap into modernity: Valencia's Regional Exhibition of 1909 would be crucial in that respect (see Lahoz 2010). This exhibition would embrace cinema, making it one of the exhibition's biggest popular draws but, symptomatically, situating it within a complex system of attractions in which the fairground, with its mechanical attractions, and the circus would be its closest neighbors (Sánchez-Biosca 2010; see "A Strange Attraction" in Chapter 17). El ciego de la aldea tells a simple story culminating in what Hollywood cinema would call "the last-minute rescue." A blind man and a little girl begging in the streets are given alms by a bourgeois couple, watched keenly by a band of robbers. The action commences with the pursuit and kidnap of the wealthy couple, and their rescue by the police thanks to the quick-wittedness of the blind man and little girl. The structure was a familiar one in American cinema but a novelty in relation to the literary adaptations being made at the time in Barcelona's film studios, and the film shows considerable technical accomplishment, exploiting the potential of depth of field in open spaces. By contrast, the moments of high drama are highly theatricalized, as was the case in American cinema. This occurs at the moment when the three groups of characters 
converge in the frame, unaware of each other's presence, thereby setting up the plot. When the conflict is resolved in the interior of the cave where the robbers are holding their kidnap victims, the sets are exaggerated. It is in this interior that the police, tipped off by the little girl and with the blind man's help, set a trap for the villains. The drama of the scene when the latter are caught in flagranti is conveyed by freezing the actors in a tableau - a convention that the cinema borrowed from late-nineteenth-century popular stage melodrama (Fell 1974).

El ciego de la aldea is thus a precocious model of what early Spanish narrative cinema is likely to have been like (the vast majority is lost). This cinema, in Tom Gunning's felicitous formulation (1986), stood halfway between the fairground attraction and narrative integration: popular in inspiration, with a gulf separating the visual regimes governing the exteriors (which make brilliant use of photography and landscape) and the interiors (whose sets are claustrophobic and rigid).

\section{Dialectics of the Avant-Garde}

One of the most radical metaphors produced on screen by the surrealist imaginary was authored in Paris by two Spaniards, Luis Buñuel and Salvador Dalí: a beautiful full moon intersected by a cloud triggered the violent irrational association of a woman's eye being slit by a razor blade (see Figure 12.1). This famous start of Un chien andalou (1929) is, however, inconceivable without the French avant-garde cultural influence propagated by Madrid's Residencia de Estudiantes (elite student hall of residence), where Buñuel, Dalí, and Lorca were formed intellectually, as well as the Paris cinema scene in which Buñuel had worked under Jean Epstein.

Despite this cultural influence, the Spanish avant-garde, although fascinated by the attempt to produce cinematic effects in words, contributed little to cinema as such, and examples of editing based on Soviet-style shock effects or intellectual montage, surrealist free association, Dadaist chance or play, futurist automation, or constructivist engineering are rare. El sexto sentido / The Sixth Sense (Nemesio Sobrevila, 1929) illustrates the ambiguous use of montage in avant-garde-influenced Spanish cinema, which remains grounded in a melodramatic imaginary. The film features a kind of drunken artist and philosopher, Kamus, who postulates the existence of a sixth sense revealed in the cinematograph. His cabinet, plunged into shadow and furnished with a camera and projector, is a stage on which the events of real life are transfigured in unexpected ways. The images projected in his cabinet are a compendium of avant-garde allusions and experiment with different forms of montage.

The first allusion is to Dziga Vertov's futurist conception of film technology as a mechanical eye, to which the protagonist attributes special powers that make 


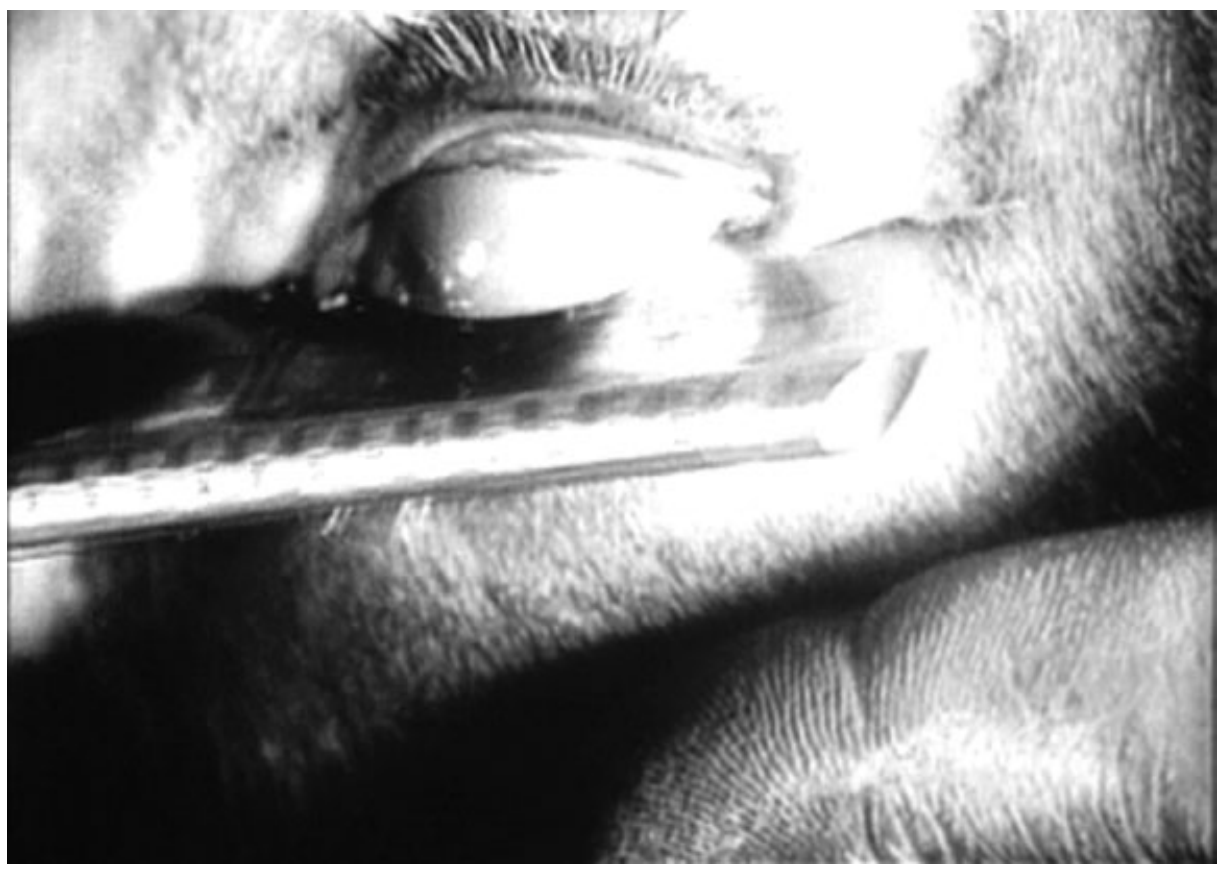

Figure 12.1 Woman's eye slit by a razor blade: the shocking prologue to Luis Buñuel's Un chien andalou (1929; prod. Pierre Schilzneck / María Portolés [Buñuel's mother]).

it a hybrid mix of Vertov's concepts of kino-pravda (film-truth) and kino-glaz (film-eye). Kamus' divinatory postulates are transcribed on intertitles:

Este ojo extrahumano nos traerá la verdad. Ve más profundamente que nosotros ... más grande, más pequeño, más deprisa, más despacio $[\ldots]$ pero yo le dejo solo... libre y él me trae lo que ve con precisión matemática. Verá usted los casos de una manera distinta. Con nuestro sexto sentido.

This extrahuman eye will bring us the truth. It's more penetrating than the human eye ... bigger, smaller, faster, slower [...] but I let it operate on its own... freely and it gives me what it sees with mathematical precision. You'll see things differently. With our sixth sense.

Despite all this, there is no automatism, no worship of technology, no homage to speed in the flow of images. The film's model of montage is reminiscent of the poetic trends that in the immediately preceding years had been the rage in France (Jean Epstein, Germaine Dulac, Marcel L'Herbier, etc.). The camera-voyeur penetrates hidden places, like a journalist's roving eye, subjected through editing to a succession of special effects: superimpositions, out-of-focus shots, sudden pans, reflections, and so on - in short, a whole catalog of techniques taken from the cinematic trend that would become known as absolute Film: the abstract films 
made by European artists such as Vikking Eggeling, Hans Richter, and Walter Ruttman, which were combined with figurative forms in Ruttman's Berlin: Die Symphonie einer Grosstadt / Berlin: Symphony of a Great City (1927). El sexto sentido thus shows itself to be familiar with editing techniques then in vogue among the French, German, and Soviet avant-gardes, but it assimilates them not programmatically but with an ironic, even burlesque, distance. Classical editing, a melodramatic structure, and a comic tone are the basic ingredients, which have grafted onto them French poetic associations, abstractions reminiscent of German experimentalism, and futurist echoes of a Vertov positioned midway between the impressionism of his newsreels and his later constructivism. A veritable cocktail.

However, the influence of 1920s avant-garde film could also lead in more conservative directions, as in La aldea maldita / The Cursed Village (Florián Rey, 1930). A rural honor drama depicting the plight of Castilian villages dependent on the land and thus on the whims of nature, it has an emotional intensity, tragic dimension, and sense of Spanishness conveyed through highly compact, confined scenarios in which the characters effectively become abstractions - that is, types or archetypes. In these earthy interiors with only interior light sources, allowing the gaze no possibility of escape, we can spot the legacy of the German Kammerspielfilm (intimate, intense psychological drama with a minimalist, almost abstract set), which, derived from theater, produced its best results in the early 1920s, gradually losing its abstract quality and veering toward the social melodrama of the decade's end. La aldea maldita still has that abstract quality. After years of drought and hailstorms, the starving peasants can see no future ahead. Acacia, a young mother, rocks the cradle of her newborn son with a mechanical gesture, her head bowed in an expression of apathy, bathed in a diffuse light. Her husband Juan approaches, bows his head in a similar gesture, and halts, not knowing what to do. That frozen, claustrophobic tableau, which the lighting turns into a space closed in on itself, evokes a host of scenes in Scherben / Shattered (Lupu Pick, 1921), Sylvester / New Year's Eve (Lupu Pick, 1924), and other metaphysical dramas scripted by Carl Mayer that were shown on German screens between 1921 and 1924.

Shortly after, the peasants, having decided to emigrate, set off in a caravan and Magda, a frivolous friend of Acacia, persuades her to leave the village, her husband (who is in jail), and their child for a better future in the city. Magda's tale mutates on screen into a collage of Madrid street scenes, materializing the fascination her words hold for the peasant woman. This sequence inevitably evokes the scene in Sunrise (F. W. Murnau, 1927) when the vamp conjures up an image of the teeming city to the male peasant Ansass, whom she has seduced. In Murnau's film, the character played by Margaret Livingston, the archetypical wicked urban vamp, gyrates wildly in front of Ansass, a peasant who has never before set eyes on the sexual license of the big city. La aldea maldita lacks the eroticism exuded by the female body in Sunrise. Nevertheless, the shared topic of the conflict between city and country, the success of Murnau's first film made in Hollywood, 
and Rey's knowledge of postexpressionist German cinema make clear the debt of his film not only to Sunrise but to 1920s German cinema in general. La aldea maldita retains the abstraction of the best of this tradition, dramatizing the tragedy of confinement.

\section{Two Iconographies of the Popular}

One of the perennial conflicts in Spanish cinema has been that between the defenders of "Spanish" forms, traditions, and iconography and those who have rejected these for more international, cosmopolitan modes. The debate, at whose heart is the so-called españolada ("typical," usually folkloric, representation of Spain; see Chapter 7), goes beyond cinema and back to at least the nineteenth century. Film was a privileged scenario for this polemic. "Typical Spanishness" could take the form of the folkloric musical, regional costumes, bullfighting scenes, rural customs, regional or ethnic stereotypes (Andalusian, Madrilenian, Aragonese, Gypsy, etc.), inflected by popular theatrical forms (zarzuela (popular operetta) or sainete (one-act farce, often with songs)), in all these cases habitually depicting the lower classes. Films drawing on this repertoire came with a ready-made stock of plastic forms (set design, costume design, props) and musical numbers (popular songs, folkloric singing stars), requiring editing techniques that showcased choreography, set design, and the centrality of performance, as in Hollywood musicals.

The 1930s were especially important in this respect. With the consolidation of sound and the construction of film studios, an array of sets were constructed and cameramen devised ways of filming them that generated a highly standardized grammar of montage (shot/reverse shot, elementary continuity editing, lack of depth of field, etc.). CEA Studios at Ciudad Lineal in Madrid were a practice ground for this codification. Two films were shot there in 1935 that encapsulate two different ways of understanding typecasting, in both cases subordinating form to choreography and musical numbers: Nobleza baturra / Aragonese Virtue (Florián Rey), by the Valencian production company CIFESA, and Don Quintin el amargao / Don Quintin the Bitter (Luis Marquina), Filmófono's first production. The shooting of the latter - an adaptation of the musical sainete by Carlos Arniches and Antonio Estremera - started on May 20, 1935, directed by Marquina under Buñuel's supervision. The film was shot in eight weeks, with a modest business plan and a technical crew hired on a fixed-term contract, including the set decorator, José María Torres, and the director of photography, José María Beltrán.

Conceived as a mix of melodrama (illegitimate children, abandonment, orphanhood, deception and revelation, expiation of guilt) and comedy (steeped in popular repartee), its lighting and editing tend to be classical and self-effacing, with the set recreating a single Madrid street - austere in comparison with the reconstruction of popular Madrid in Benito Perojo's La verbena de la Paloma / 
Festival of the Virgin of the Dove, shot the same year in the same studios (with sets by Fernando Mignoni). But one special feature stands out in this grotesque tragicomedy: the staging of the musical numbers. Filmófono's director, Ricardo Urgoiti, had been the head of Unión Radio, the founder of the record label Rékord, and had launched a system of synchronized film sound based on the Vitaphone soundon-disk system. The soundtrack of Don Quintin is notable in two respects: the costumbrista ("typical" lower-class) language, colloquialisms, and popular intonation of most of the characters; and the way it handles the songs.

Let us take an example. Don Quintín's bitterness has become a talking point throughout the city, and a song about it is sung in bars and public places, and has even been issued as a gramophone record. At the customers' request, a waiter gets out a copy of the record, which he keeps carefully stored, and plays it to everyone's delight. As if by magic, the regulars engaged in conversation, the lovers petting, and the beggars eking out their daily ration join in and sing along. Out of the blue, Don Quintín comes into the bar and, although the waiter takes the record off the gramophone and turns on the radio, it happens that the radio announces to its listeners the famous song... "Don Quintín el amargao." Furious, Don Quintín insists that the record be handed over to him; he puts it on and then smashes it. We thus see how, in no time at all, the song's success has spread to every corner of Madrid. As well as being sung and played on the gramophone and radio within the diegesis, the song of Don Quintín was also the film's extradiegetic theme tune. Urgoiti thus inscribed his multiple professional activities onto the film at a structural level.

Turning to Nobleza baturra, the film opens with a striking sequence. In a sea of wheat extending as far as the eye can see, men and women are busy harvesting. Brilliant light and meticulously orchestrated crosscutting between the men and women alternate with lavish travelling shots following the protagonist, María del Pilar (Imperio Argentina), as she drives a pair of oxen. The camera movements together with the editing and sunlit exteriors are a technical tour de force that additionally testifies to CIFESA's economic capacity, combining Enrique Guerner's skills as a cameraman with Rey's directorial preciosity. The spectacularity achieved by the camerawork is not undermined by the constant crosscutting, thanks to the continuity provided by the song "La Magallonera" sung by the protagonist. This use of a striking opening travelling shot would be repeated in at least two later CIFESA films involving Rey and Guerner. The first is the travelling shot that opens Morena Clara / Dark and Bright (1936), in which the camera enters the Venta de los Platillos as if representing the gaze of a character, fades into the arrival of a waiter whom the camera then tracks, moves to frame a scene taking place the other side of a doorway, and returns to the waiter. All this meant complicated acrobatics for a heavy camera in 1936, and coordination between direction of the actors, narrative point of view, and adjustment of the camera lens to film at variable distances, exploiting depth of field and movement. In the second example, from 1940, with a plot similar to that of Nobleza baturra, the super-production La Dolores would start with a sophisticated travelling shot that takes us through the 
varied activities of rural life, from agriculture to cattle-raising. The travelling shot ends with the camera coming to rest on the protagonist, Concha Piquer, who starts to sing as she milks a cow. All the resources of mise-en-scène are mobilized here to showcase the star.

Also worth mentioning is the way in which Nobleza baturra adapts camerawork to set design in its depiction of the Aragonese village in the scene of the procession of the Virgin of the Rosary, when María del Pilar is slandered. Guerner sought out his camera positions with care, framing his shots through archways with a background of black silhouettes illumined by the lanterns carried by the men. This constant virtuoso camerawork became Guerner's authorial signature. The same virtuosity is found in the spectacular dance in the Andalusian patio of Morena Clara, celebrating the fiesta of the Cruces de Mayo, for which Guerner both positioned a camera behind a window grille and used a bird's eye view shot to highlight the fountain and female costumes. This use of depth of field and the positioning of the camera behind an object in the foreground are also found in the dancing and singing numbers in La Dolores, in which Guerner filmed through both a cartwheel and a window grille. In sum, the camera's arabesques are placed in the service of a lavish, recognizable typecasting, whose principal ingredients are directorial style, set design, lighting, and the centrality of the female star.

\section{From Propaganda Documentary to Plush Interiors}

Just when the number of films shot in film studios was taking off, civil war broke out as a result of the military uprising of July 1936. Spain was overrun by news cameramen, and those who had developed expertise in filming pictorially conceived studio sets were thrust into the unpredictability of the battlefield. Newsreels and documentaries of the Civil War are discussed in Chapter 18; here I limit myself to noting the technical upheaval that the war entailed: anarchist documentary filmmakers rushed to the front; Guerner and other exquisite cameramen had to turn to making propaganda films; Nazi models of montage (counterpropaganda, recycling of enemy footage) reached Spain; and Buñuel helped to edit España 1936 / Spain 1936 (Jean-Paul Le Chanois, 1937), in which he accentuated the film's capacity to shock. Nothing illustrates the change so graphically as this last film, together with, on the Nationalist side, España heroica / Heroic Spain (1938), in which Joaquín Reig forged a model of intellectual montage without shooting a single take (see Chapter 18). However, Franco's victory in 1939 would soon take Spanish cinema back to the studios, and to the production of genre films and a new kind of standardization. How should this postwar production be defined?

El clavo / The Nail (Rafael Gil, 1944) offers a model. Adapted from a novel by the canonical late-nineteenth-century novelist Pedro Antonio de Alarcón and drawing on the genre of the fantastic, the film, produced by CIFESA in the early 
postwar period with sets by Enrique Alarcón and photography by Alfredo Fraile, is a significant example of the return to films characterized by a self-contained environment, making reality opaque. This effect was created by meticulous attention to mise-en-scène, with sets modeled on a stereotypical vision of the nineteenth century, camerawork that showcased the actors (Rafael Durán and Amparo Rivelles) and added a sinister note to the action, and a self-effacing editing style in keeping with the models of classical narration developed by Hollywood after the move to sound. Certain aspects of this film speak eloquently to the hermetic quality that cinema strove to achieve in the great age of the studio system, with its roster of stars, recourse to genre cinema, and unassertive editing. Neutral to the point of excess, El clavo represents a style within Spanish cinema that would be slow to decline, keeping the protective environment of the film studio in operation until very late.

\section{Claustrophic Lighting}

Nada / Nothing (Edgar Neville, 1947) opens and closes with the voiceover of Andrea narrating her arrival in Barcelona from the countryside in order to study at university, full of illusions about her future prospects. A few months later, having lived through a devastating drama, that same voice picks up the story as she leaves, taking away with her "absolutamente nada" (absolutely nothing). This voiceover reproduces the first-person narration used by Carmen Laforet in her novel of the same title. In the film, the opening first-person voiceover economically announces the personal focus that will impregnate the whole narrative. On a rainy night, a taxi pulls up outside an apartment block, and the camera accompanies the female protagonist as she enters a dark world where there is no electric light. Lit by the flame of a match, she goes up the stairs, the camera following her from behind, and waits outside the apartment door, viewed from behind the banisters. The camera slowly zooms in on the young woman, highlighting her entry into the hermetically sealed, sinister world where her relatives tear each other apart and where she will be greeted like a ghost from the past. After the brief return of her voiceover at the end, the camera turns 180 degrees to go back inside the building, from which it frames a brightly lit street. As Andrea leaves, the camera, now in the doorway, goes indoors, pans the darkness, moves through the archway leading to the inner courtyard, and turns so as to aim up the empty stairwell down which Román had flung himself shortly before in a strange "accidental" suicide. Dissonant music adds to the sinister quality of this closing travelling shot.

This narrative framework illustrates the oppressive atmosphere that camerawork and set design will, throughout the film, imprint on a succession of events structured by the sordid relationships of Andrea's relatives, creating a sense of entrapment that echoes her feelings as a newly arrived observer. The unhinged 
plot probably benefited from the cuts that CIFESA imposed to alleviate the film's depressing atmosphere (Pérez Perucha 1982). The grandmother and her childrenAngustias (who has an obscure past relating to the war and is her boss' lover), Román (imprisoned during the war and now a musician, black-marketeer, and above all sadistic seducer who ruined the life of the mother of Andrea's friend Ena, who takes her revenge during the course of the film), and Juan (mentally unstable and married to Gloria, who has an equally sordid background and maintains the family by gambling in the red-light district) - configure a narrative web of which only loose strands emerge. Two things are responsible for the film's mood: camerawork and sets. It is a world of cramped interiors, with the ceilings weighing on the characters and a pronounced depth of field, reinforced by an acting style of barely suppressed hysteria. The set recalls the low ceilings designed by Perry Ferguson for Citizen Kane (Orson Wells, 1941), filmed by Gregg Toland with extreme low-angle shots. Since Welles' first film was not released in Spain until 1967 , it is likely that the similar but less obviously distorted camerawork of Stanley Cortez for The Magnificent Ambersons (Welles, 1942) was the inspiration for Nada's director of photography, Manuel Berenguer. Sigfrido Burmann's set designs for Román's attic show the express aim of creating a tortured look (Gorostiza 1997: 59). Indeed, the combination of plot, subjective point of view, cramped sets, and the photography's strong black/white contrasts and sense of unreality produce one of the most asphyxiating environments in Spanish cinema, giving plastic form to the sense of derangement. This is so much the case that even Juan and Andrea's night-time expedition to Barcelona's red-light district, with its maze of narrow streets, takes on a claustrophobic quality, if one compares it to the incipient realism of a film of the following year, La calle sin sol / The Sunless Street (Rafael Gil, 1948).

\section{Sets for a Cardboard Version of History}

The highly successful Locura de amor / The Mad Queen (Juan de Orduña, 1948) was part of the cycle of historical epics that scholars have so despised, condemning these films as retrograde and as unquestioningly propounding official dogma. It has become standard for histories of Spanish cinema to say that, at the end of 1950, Alba de América / Dawn of America (Orduña, released 1951) represented the historical trappings of a outdated cinema, while Surcos / Furrows (José Antonio Nieves Conde, released 1951) represented the realist future for which the shortlived Director General of Film and Theater, José María García Escudero, fought and was defeated (see the sections in Chapter 14 on censorship and CIFESA). Locura de amor's start hints at its mode of composition: the image over which the opening credits appear is a rendering of Francisco Pradilla's painting Doña Juana la Loca (1877). Over it appears the title of Manuel Tamayo y Baus' historical drama Locura de amor (1855), on which the screenplay (written by none other than 


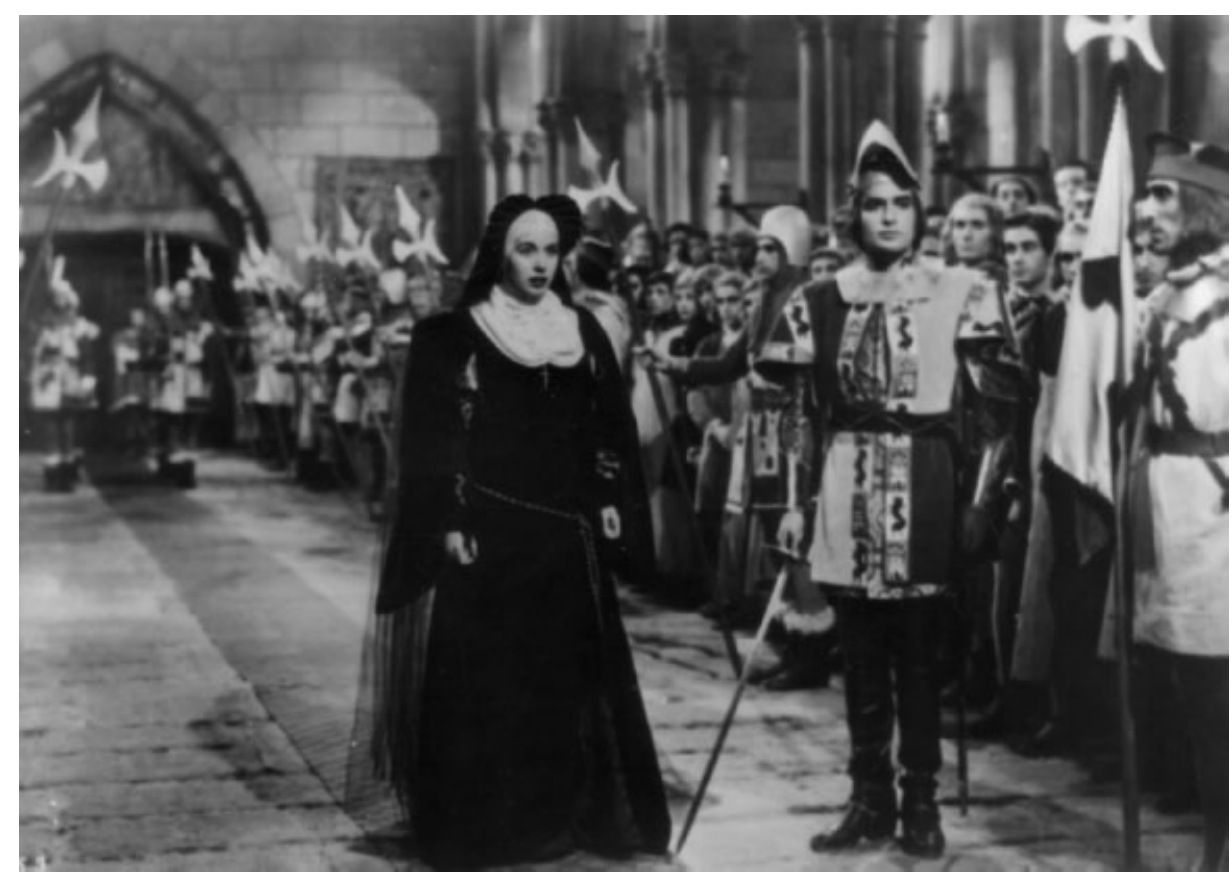

Figure 12.2 An example of the statuesque, theatrical mise-en-scène favored by CIFESA's historical epics: Aurora Batista as Juana la Loca in Locura de amor (Juan de Orduña, 1948). Courtesy of Video Mercury and Filmoteca Española.

the dramatist's grandson Manuel Tamayo together with Alfredo Echegaray) was based. The painterly reference attests to the authority of an iconography generated by the historical painting genre that shaped nineteenth-century cultural tastes, instituting a visual imaginary and repertoire of legends surrounding national history, which was co-opted by the nation-formation process. In drawing on this source, the film reinforced pictorialism and frozen tableau effects at the expense of dynamic editing and narrative pace. Tamayo y Baus' play added a dose of postRomantic emotionalism, played up by Aurora Bautista's exaggerated diction in the role of Juana. The film's opening image thus evoked a recognizable universe.

The static pictorial-theatrical quality of the sets, props, and camerawork (see Figure 12.2) is offset by certain traumatic editing effects, such as that triggered in the now aged, confined queen by the sight of the insignia of the Golden Fleece, which cuts to her hallucination of the villain Filiberto de Vere. As occurs frequently in CIFESA's historical epic cycle, the story from the past is framed by a narrator recounting it at a later point of time - in this case Alvar de Estúñiga, who relates it to none other than the Holy Roman Emperor Charles V (King Charles I of Spain). The narrator's voice gives way to a heavily furnished interior in which Juana's mother, Queen Isabella, lies dying. The composition of this frame, which serves as a portico to the drama, is modeled on another nineteenth-century canvas, 
Eduardo Rosales' El testamento de Isabel la Católica / The Testament of Isabella the Catholic (1864), though this time the stasis is broken by a gentle travelling shot.

These two paintings represent the two poles between which the film moves: Pradilla's canvas highlights the truculent element, with its ghoulish coffin, the Habsburg coat of arms, and the pregnant widow in the midst of a windswept landscape, whereas that of Rosales transmits a maternal serenity to a scene that presages future disintegration. Just before the film's end, Juana caresses her husband Philip I - known as Felipe el Hermoso (Philip the Handsome) - on his sick bed, not realizing he is dead. To her courtiers' stupefaction, she stands up and requests silence since "el rey se ha dormido" (the king is asleep). With this Orduña inscribes another classic pictorial reference, to Lorenzo Vallés' painting Demencia de doña Juana / Madness of Doña Juana of 1866.

The film's self-conscious staginess (diction, entrances and exits, costumes, and sets and props) is reinforced by the omnipresent pictorial references: Albert Bouts, Van Eyck, Roger van der Weyden, among others (Seguin 1997). The historical research and costumes were entrusted to Manuel Comba (son of the court painter of Alfonso XII and Alfonso XIII, Juan Comba), who was married to the great-granddaughter of the historical painter Eduardo Rosales. To produce this painterly effect, no less than thirty set designs by Sigfrido Burmann were constructed by Enrique Bronchalo. The film's end is highly indicative of this desire to create historical tableaux derived from nineteenth-century historical painting: the dark scene of the coffin that opened the film reappears, this time painstakingly recreated by the actors, bearing witness to the morbid, deathobsessed legend. The rigidity of the sets and the overacting were such between 1947 and 1951 (Fanés 1982: 164-81) that when Juan Antonio Bardem and Luis García Berlanga made their first film - Esa pareja feliz / That Happy Couple (filmed 1951, released 1953) - they opened it with the shooting of a historical film; the sequence ends with the destruction of the set and all the lighting equipment.

\section{Openings to Modernity: Realism and Editing}

In the history of film form, perhaps the most significant break occurred at the end of the 1950s. Even if we allow for a certain amount of temporal slippage, a series of factors - industrial, technical, aesthetic, and relating to social sensibility determined the end of an era centered on the great Hollywood studios, genre cinema, and mass production. These multiple factors ranged from the jolt produced by television to a new perception of the real heralded by neo-realism but that only became standard with the generalized use of direct sound and highsensitivity film. The fondness for exteriors, use of lighter cameras, and influence of news reporting went together with a preference for using lighting to create atmosphere rather than to showcase the stars. Spain was not a pioneer in these 
changes; the daring innovations came from New York, the Nouvelle Vague, Free Cinema in Britain, and even New German Cinema. Symptomatic of this conservatism was the fact that film studios survived in Spain until the late 1970s. However, the main lines of modern cinema can be squarely identified in Spanish film. Four areas of aesthetic renewal deserve mention.

First, the perceptible efforts from the early 1950s to accommodate techniques of fragmentation and location shooting show the influence of news reporting, especially in a genre little studied from a formal point of view: the thriller (Medina 2000). Getting out of the studios, lighting real-life interiors, segmenting narrative and space in keeping with the techniques of modern mass culture - all these are reactions against the grammar of continuity editing and theatrical illumination that went with the studio system. Brigada criminal / Crime Squad (Ignacio F. Iquino, 1950) is a curious example of the stylistic crossings that took place in the early 1950s: on the one hand, the traces of the American thriller and courtroom drama (Palacio 1997) are evident in the strong black/ white contrasts, iconography of the gangster, and phantasmagoric interiors with almost abstract lighting; on the other, the documentation of urban life (Madrid and Barcelona) gives an impression of randomness and improvisation. Added to this is the use of journalistic techniques of condensation through the voiceover narration of a police chief, modeled on Fritz Lang's M (1931).

Second, there was an attempt in this same period to create the impression that the reality being filmed exists independently from what is captured by the camera. A sophisticated use of camerawork goes together with meticulous directing of the actors, crosscutting, the layering of sound, and the overlapping of storylines. Nothing illustrates this better than Berlanga's long takes of choral actions that are not subjected to the restrictions of controlled dramatic composition, as if the camera had been "invited in." In an interview given in 1964, Francisco Sempere, the director of photography for Berlanga’s Plácido (1961), described Berlanga’s shooting method as follows:

Para rodar estos planos-secuencia, en donde luego no se puede cortar ni intercalar nada, hay que saber [...] marcar ya en el rodaje el ritmo de la interpretación y del movimiento de los actores. En una palabra, hay que poseer un completo dominio de todos los factores que entran en juego y tener una intención. En cuanto al método de trabajo, empezábamos por ensayar mucho, con la grúa, actores, luces. A las dos de la tarde estábamos en el plató y se iniciaban los ensayos. Unas cuatro horas después, hacia las seis, empezábamos a rodar. (López Clemente 1989: 349)

To shoot these sequence shots, where you can't make cuts or add anything later, you have to know, at the time of shooting, how to [...] maintain the rhythm of the actors' performance and movements. That is, you need to have complete control of all the factors involved and know where you are going. As for our working method, first we'd rehearse intensively, with the crane, the actors, the lighting. We'd be on the set at 2 p.m. and the rehearsals would begin. Four hours later, around 6 p.m., we'd start to shoot. 
It is worth comparing this strategy with that of Guerner-Florián Rey, discussed above. In that example, the camera drew attention to itself in a composition where the light was trained on the actors and the director organized what appears on screen according to a hierarchy of dramatic intensity. In Berlanga's case, by contrast, the camera loses that aloofness and tends toward self-effacement. The movements are made by the characters, with their mobility conveyed through a layering of sounds (with several characters talking at once) and images (with several groups of characters passing each other in different directions, or the action splitting into two or being interrupted by another action). Sempere's camera tries to capture something going on just out of reach, though it is of course his manipulation of the camera that creates that impression. These are not so much sequence shots as a multiplicity of characters, images, and sounds held together by unity of time and place. Plácido is a good example since it has several overlaid plotlines, none of which takes priority over the others. Plácido (Cassen) tries to pay the next instalment on the three-wheeler he has bought on credit; Gabino Quintinilla (José Luis López Vázquez) takes charge of organizing the festivities; the chairman of Cocinex Cookware oversees the publicity for his product. These actions overlap with the misadventures of the beggars and artists seated at the tables of their wealthy hosts. On top of this, other actions and characters intrude sporadically, only to vanish. The direction of the actors has to be perfectly synchronized with the manipulation of the camera, so that the camera can mingle with the actors without attracting attention or prioritizing any particular aspect.

A more radical sign of this modernity - the third feature discussed here - is found in Los chicos / The Young Ones (Marco Ferreri, 1960), for which Sempere was also director of photography. At the edge of the frame, leaning against a tree, one of the young protagonists, El Negro, is waiting for something. In the background is a busy street. El Negro's gaze is trained on a bar whose exterior he watched keenly in a previous scene. A couple comes out of the bar and walks to an alleyway on the right. At that point, El Negro moves toward the couple, who disappear into the alleyway. The next shot picks up the action from the alleyway, filmed in deep focus but with no visual distortion. The couple - El Negro's mother and her lover - pass in front of the camera and continue on their way; the camera waits for their pursuer and then follows him in a pan after which we see him disappear into the distance. The sense of real time is crucial to this shot, as is the neutrality of the camera's gaze, filming everything in its view without emphasizing anything in particular. The couple disappears at the entrance to a boarding house; El Negro's face, now filmed in medium shot, stiffens; behind him, a group of passersby comment on how such "boarding houses" are great money-makers, "happening" to express what the boy's face registers as a stab of pain. This sequence is symptomatic of Sempere's use of the camera/gaze in Los chicos: the depiction of the four boy protagonists in their different habitats by means of deep-focus compositions, with objects in the foreground, fills in the moral and psychological context of family and work. But, as with Berlanga, there is a complete absence of dramatization. Filming in 
the street, refusing to prioritize, opting for multiple protagonists - all of these factors signal the modernity that would put an end to the studios' mystique. Subject matter and expression, editing and composition, exterior locations, and the large cast of characters combine to announce new times. Of course the radical aesthetics of John Cassavetes' Shadows (1960) is on a different scale from the innovations of Los chicos: Ferreri's film has no jump cuts, documentary-style grainy $16 \mathrm{~mm}$ images, or actors improvising. The script, photography, composition, directing of the actors, and editing follow more classical guidelines.

The fourth feature that deserves to be singled out does take experimentation further: namely, the combination of realism and allegory, of the apparently real and the hallucinatory, achieved by the photography of Luis Cuadrado in La caza / The Hunt (Carlos Saura, 1965), where the use of a mobile camera (borrowed from television reporting) and long takes are combined with overexposures, black/ white contrasts taken to the extreme, and near-experimental editing of narrative and sound. La caza is untypical of 1960s Spanish cinema: it picks up on the decade's fondness for exteriors and its agile camera roves around the bleakness of the barren hills; but it also experiments with the characters' interior monologues, and with the dissonance and atonalism of Luis de Pablo's musical score. Converting the landscape into a tragic scenario, exploring the effects on faces and bodies of the sweltering heat, Luis Cuadrado produced a strange blend of realism and experimentalism, shooting through a filter to accentuate the contrasts and overexposing the film to produce an almost burned look (see Figure 12.3). Nor is editing neglected, with its unexpected jumps that alternate establishing shots of the landscape with extreme close-ups of the characters that probe their states of mind, its shifts of focus, and its zooms. In short, the film combines the resources of editing with those of a mobile camera. The paradoxical result is a film that shades into allegory precisely because of its extreme realism.

\section{Choreography and Musical Design: Something Different}

Diferente / Different (Luis María Delgado, 1962) is an anomalous film within Spanish cinema. A bizarre narrative built around a homosexual imaginary (by the dancer and choreographer Alfredo Alaria) whose (unspoken) theme is just that, it was a unique example at that time of a film musical that had nothing to do with the españolada, with its folkloric or popular female singing star. The film is structured around a series of set designs with a pre-cinematic function: that of showcasing choreography and dance. If in the españolada the sets, costumes, and props serve to highlight an exotic Spain, in Diferente the dancer's personal imaginary invades the whole production design: the sets are those of the successive dance numbers that make up the film, and the latter, in turn, are not narrative performances by the actor (as in the backstage musical) but dream 

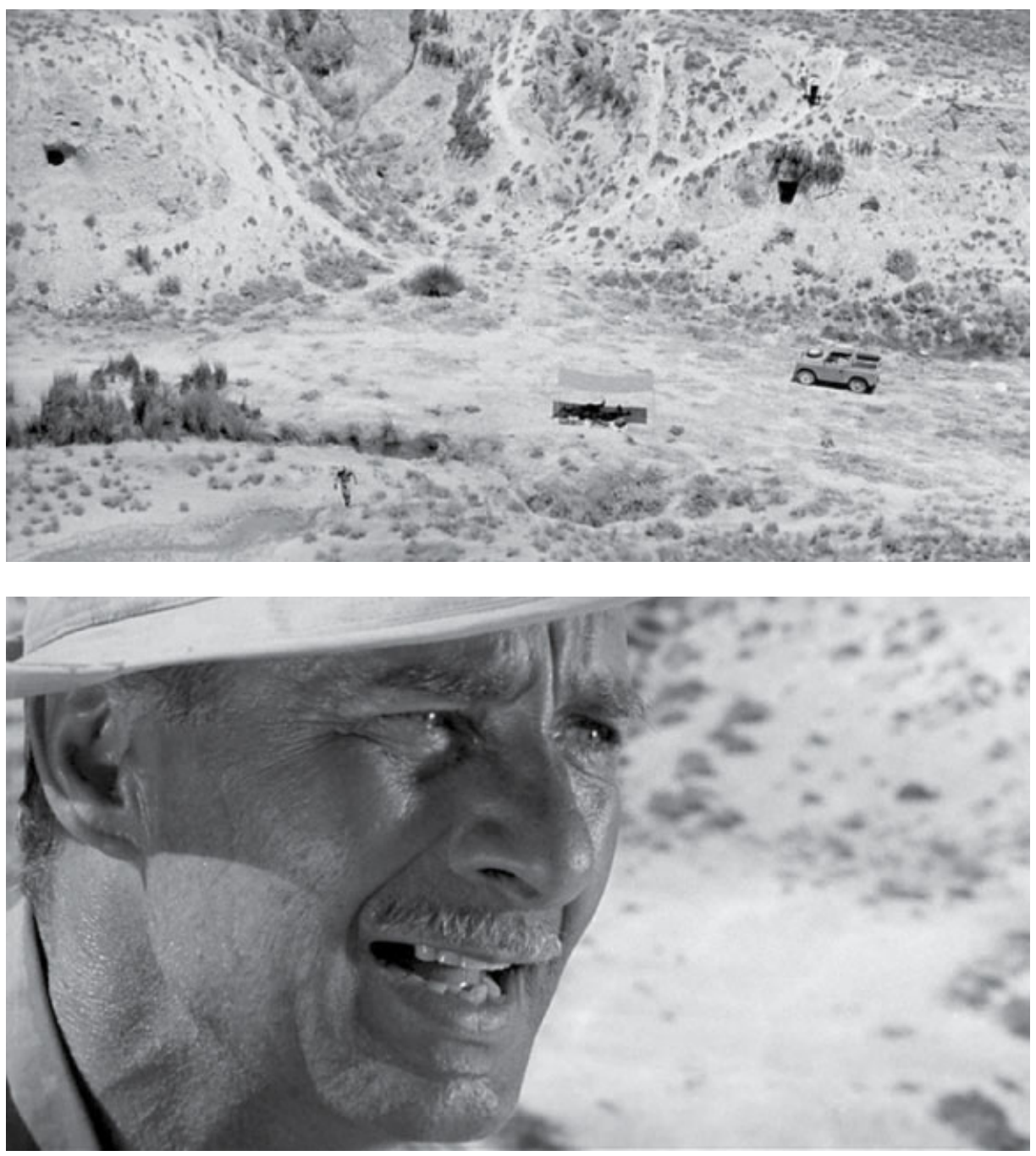

Figure 12.3 Sunburned landscape and faces as harbingers of tragedy in Carlos Saura's $\mathrm{La}$ caza (1965; prod. Elías Querejeta PC).

sequences, ideas, divertimentos. In other words, the whole film depends on the sets inasmuch as they are a metaphorical, narrative, and psychological projection of the demiurge that gives birth to it.

The film's production design involves the integration of several features: first, the set designs for the locations depicted (associated with jazz, native dance, etc.); second, the choreography or movement of the dancers on stage, starting with the protagonist; and third, the imaginative condensation of these spaces, liberated from the tyranny of the real and giving way to abstraction (saturation of color, allegory, etc.). The film's self-referentiality also derives from its citations: West 
Side Story (Jerome Robbins and Robert Wise, 1961), in the scene of a rough fight in a night club; the use of recurring motifs in Kenneth Anger's Fireworks (1947), in the deflationary toppling of the Christmas tree.

\section{Holding the Image: The Aesthetics of the Static Shot}

The credits of El espiritu de la colmena / The Spirit of the Beehive (Víctor Erice, 1973) plunge the spectator into a child's world of make-believe: drawings by the two child protagonists (Isabel and Ana); a banner with the fairy-tale invocation "Érase una vez" (Once upon a time); a vaguely specified time and place (start of the 1940s, a village in Castile). The whole film retains this dimension of makebelieve: songs and jingles, leafing through a family album, viewing a film, a sense of the mysteries of death hovering in every corner. This recreation of childhood experience takes on a particular tone thanks to the use of color, the composition of the frame, the length of the takes, and the takes' relation to the soundtrack.

Luis Cuadrado (the cinematographer for Saura's La caza, as we have seen) gave the camerawork an ochre color that seems to emanate from the bees buzzing around the hive tended by the father of the family, Fernando (Fernando Fernán Gomez). This honey color bathes the interior spaces, and Fernando's room looks out onto the garden through a window made of ochre-colored glass panes shaped like the cells of a honeycomb. This yellow hue is one of the features that give the film its melancholy atmosphere, reinforced by the scale of many of the shots. Erice chose to film the Castilian plain through long shots of the open horizon, which forms an unattainable or infinite vanishing point, literalized in the shot of the railway tracks whose lines stretching into the distance will never meet. Within this vastness, the figure of a little girl, her back turned to us, scrutinizes the barren landscape, fixing her gaze on the ruined hut with a well where the ghost of the past (for Ana, an emanation of the monster in the film Frankenstein; for us as spectators, the past of the Civil War) will appear. The takes are long and silent, or at least wordless, the only sound being the relentless howling of the wind.

This minimalist composition and the predilection for persistent, static long takes (each space is represented by a take that is repeated each time it reappears) have their correlation in the film's muteness. The lack of sound makes the film's effects audible. The characters gaze and meditate, write letters to an addressee they will not reach (the children's mother, Teresa), get bogged down in literary descriptions of the buzzing of the bees (Fernando), whisper in the quiet of the night (the little girls), and contemplate the traces of an unknown past via a family photo album (Ana). The sense of absence is echoed in the shots of the open plain, which stress how tiny Ana and Isabel are in comparison with the imposing 
landscape. In these long shots, the figures of the little girls, especially Ana, act as a prop against which the vastness of the open horizon makes itself felt; on occasion they lose themselves in it as they run into the distance. At such moments the empty countryside becomes an actor, indicating a temporal ellipsis, as in the sequence in which Ana goes back to the recently discovered spot that she intuits is the haunt of the spirit her sister has told her about - the passage of time is subtly suggested by the change of color of her socks.

This scenario of solitude and reverie, where the gaze confronts an empty landscape, has a counterpart in the sequence in which Ana's fascinated gaze acts as the reverse shot to the screen on which the film Frankenstein (James Whale, 1931) is being shown - the only part of the film we see is the encounter between the little girl and the monster. In the darkness of the improvised cinema, the shot/ reverse shot alternation between the screen image's interpellation of Ana and her intense look back forms a self-contained loop that will culminate in the materialization of the ghost in the wounded resistance fighter whom the little girl will tend and feed. After this shot/reverse shot exchange between the screen and Ana's passionate gaze back at it, Ana is overwhelmed by the specter of absence and, on the night she runs away, imagines her encounter with the monster in the film. The compositional minimalism, the extreme economy in the selection of shots, and the capacity of the camerawork to recreate states of mind are perhaps the reasons why this film has so influenced later Spanish cinema. One can even talk of a "Querejeta look," given the recognizable style that characterizes the films he produced - whether directed by Saura or Erice, Jaime Chávarri or Manuel Gutiérrez Aragón, Francisco Regueiro or Montxo Armendáriz - and which impregnates the photography of cameramen as different as José Luis Alcaine, Teo Escamilla, and Cuadrado (see the section "The Producer-Author as Transational Entrepreneur" in Chapter 2). Numerous films of the 1980s would inherit this style in their lingering recreation of places and times marking the sentimental education of Spanish children - a sentimental education soured by the Civil War or Francoism. Most of these would lack the equilibrium that El espiritu de la colmena achieved between emotional tone, camerawork, sobriety, silence, length of take, and the sense of time lived as reverie.

\section{A New Experimental Avant-Garde}

Arrebato / Rapture (Iván Zulueta, 1980; see Chapter 21) is imbued with US underground culture, making use of collage, fragmentation, and recycling. Its visual regime draws on comics and horror films, and has little to do with the literary-based cinema dominant in Spain at the time. Having previously authored several experimentally inspired shorts, in Arrebato Zulueta gives narrative form-visually attractive and delirious in its treatment of drugs - to a series of topics that had been 
recurrent in experimental cinema since the 1950s: home movies, found footage, conceptualism, and minimalism, including the "rediscovery" of cinema in Warhol's early films, such as Sleep (1963). The central theme of Arrebato is the pause, the suspension of movement, a concern of those filmmakers who had set out to rethink the mechanisms for capturing and projecting images: Michael Snow, Hollis Frampton, and Ernie Gehr in North America, but also Kurt Kren and Peter Kubelka in Europe. Indeed, the red frame to which Pedro (Will More) attributes the camera's devouring of his life is a reference to Schwechater, a film made by Kubelka in 1957-8 with 1440 different units in black and white. Kubelka had in his montage used a structure based on blocks of red, each lasting for thirty frames and recurring at decreasing intervals, comprising what he called "metric cinema." Pedro, however - like the protagonist José (Eusebio Poncela) on his behalf responds to this meditation on red in a passionate, compulsive manner.

At the same time, Zulueta's two main characters probe their everyday surroundings with their camera pretty much as if they were making a home movie, except that they have no memorializing impulse (as in the work of Jonas Mekas) and are not driven by an interrogating inner eye that transfigures the real (as in Stan Brakhage) nor by an urge to exhibit the private in public (as in Carolee Schneeman). Much of the footage projected within the film comes from a Super $8 \mathrm{~mm}$ travelogue shot by Pedro, speeded up so as to become something unrecognizable, if not sinister. This mix of sources, textures, and formats - including the recycling of material previously filmed by Zulueta himself - evokes the indiscriminate hybridization that contemporary documentary calls "found footage."

That this atypical film, with its complex intertextual references, should have become a cult movie for much of the general public is quite extraordinary. The reasons were partly to do with the author's reputation as a maldito (doomed artist) but also with the film's treatment of the topic of heroin at a key moment in Spanish culture (the transition to democracy) - a topic that the film assimilates to the metaphor of vampirism. If Almodóvar introduced pastiche into Spanish cinema of the same period - in the sense of a masquerade or detached ironic allusion, the definition of the term given by Fredric Jameson in his study of postmodernism (1992) - Zulueta played up the passion and drama of the modern subject, its inner lacerations and eventual destruction. This and the many cinephile textual references in the film obscured for the general public the film's recourse to the subject matter, style, genres, and problematics of experimental cinema.

\section{From Eccentricity to Designer Look}

The screen is taken over by cuttings from fashion magazines; the colors are bright, the contours clear. Lingerie, gloves, evening gowns, high-heeled shoes - all highly sophisticated. Painted fingernails drying after a manicure, red lipstick, dressmakers' 
scissors, an eye painted with eye-shadow repeated in a strip of pristine shots from a photo booth. Over these images, the beat of a bolero with its inevitable lyrics of betrayal in love. The culminating image of these credits: a camera on a film set. Immediately, a female voice transports us to what appears to be a farmyard but turns out to be an improvised chicken coop on a city terrace. A single shot condenses the core of the melodrama: the back of an old LP, on which a red felt-tip pen has turned the title of a song into a declaration of eternal love; to its left, an ashtray filled with sweet wrappers and a cigarette end; behind it, a coaster with a forgotten drink against a red background. A man's voice repeats the promise of love. Next, an alarm clock; the camera pans to the photograph of a couple, inscribed with a handwritten message signed by someone called "Iván"; then an empty pack of pills; then another alarm clock, its hands indicating the same time as the last one: eight o'clock.

This is the start of Mujeres al borde de un ataque de nervios / Women on the Verge of a Nervous Breakdown (Pedro Almodóvar, 1988). The essence of melodrama is condensed in these shots: the bolero, the woman's story, the kitsch picture, redundancy. Even before we are made aware of the standard plot of love betrayed, the credits indicate an aesthetic: the fragment, the magazine cuttings, fashion, fetishization of the female body and women's clothes, in frames saturated with bright colors and littered with scraps of dress material (see Figure 12.4). We could be in the workshop of a dressmaker or fashion designer. All the same, the tone is uniform; José Luis Alcaine's camerawork homogenizes the fragments in a postmodern design that is impeccably kitsch and camp.

This start is remarkably similar to that of Almodóvar's first film, Pepi, Luci, Bom yotras chicas del montón / Pepi, Luci, Bom and Other Girls on the Heap (1980): grotesque drawings, references to comics, accompanied by rock music of the day, and again ending with the image of a camera on a film set, cutting to the same actress, Carmen Maura, this time collapsed on a bed. And yet, even before the narrative has started, we can see a host of revealing differences with regard to Mujeres: the coarse quality of the sound and image, the provocatively grungy textures, the glaring references to Warhol. Separating these two films - nearly a decade apart - is the conquest of a designer look, an elegant style that, no matter how outrageous the storylines, enhances its flawless composition by citing hallowed sources: Douglas Sirk and his mannerist use of color, framing a universe of postmodern female fetishes where retro and design-consciousness rule. This formal slickness, which encompasses editing, camerawork, and production design, would become a constant of Almodóvar's subsequent work. Collage but without disorder, pastiche but with its nods to the underground subtly designed.

What is involved here is the harmonization of a style to which all formal elements are subordinated, artificially provoking the desired effect, as in Umberto Eco's definition of kitsch (1968: 82). Nothing illustrates this so well as Todo sobre mi madre / All about My Mother (1999), released just over a decade after Mujeres. The references are to an array of gay icons that time and tradition have codified as ingredients of over-the-top melodrama: All about Eve (Joseph L. Mankiewicz, 

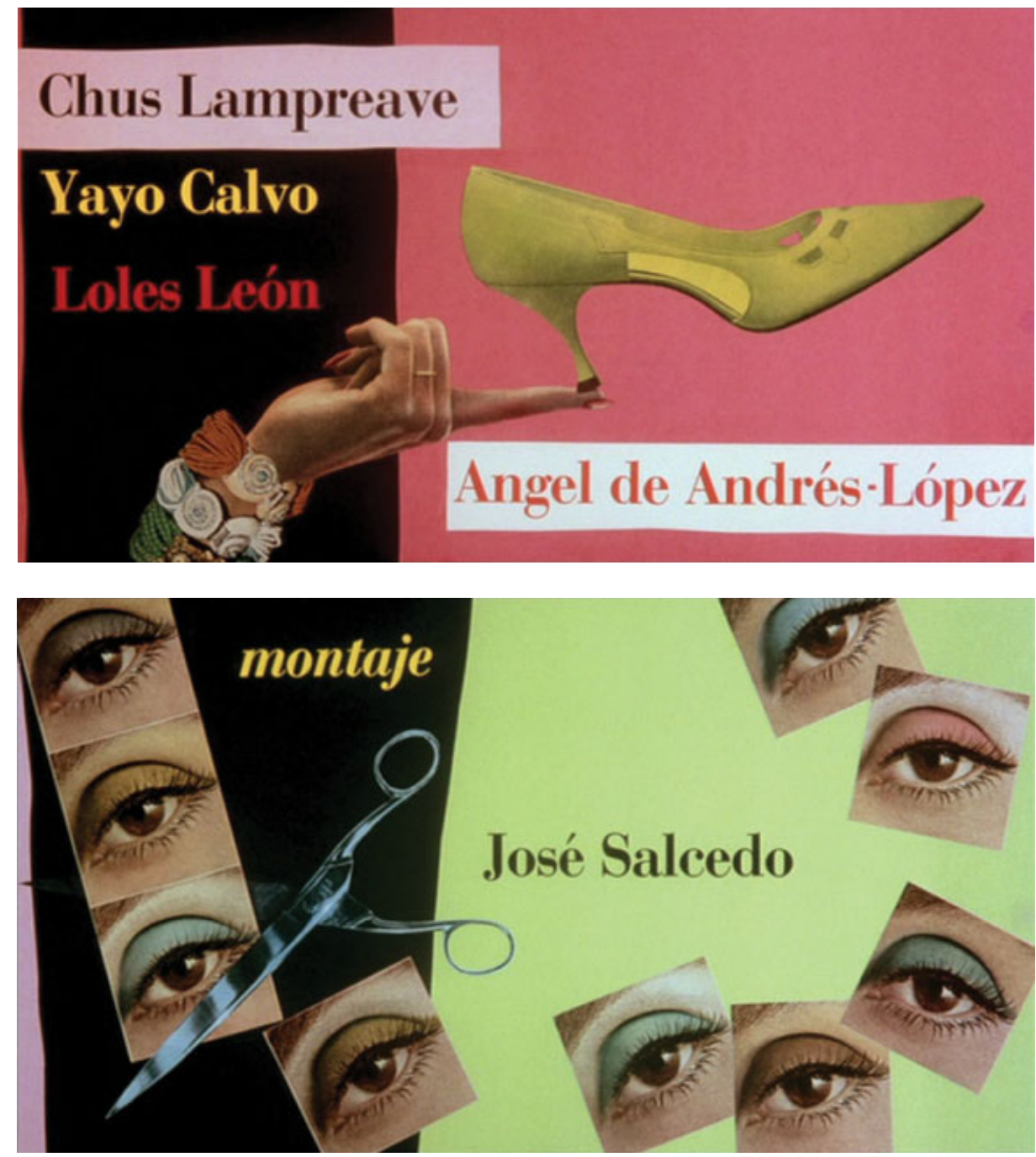

Figure 12.4 Mujeres al borde de un ataque de nervios (Pedro Almodóvar, 1988; prod. El Deseo): fetishization, collage, and postmodern design.

1950), the theater world as a scenario of exaggerated performance and fakery, and the explicit quotation of Opening Night (John Cassavetes, 1977).

\section{Stylistic Diversification}

The highly fragmented panorama of the last few decades invites analysis from a political, cultural, or gender perspective more obviously than from a formal point of view. Nonetheless, I will end by sketching out a few formal trends, with no 
pretensions to comprehensive coverage. One identifiable avenue is that opened up by El espiritu de la colmena, exploring the dimensions of time and silence in an everyday life ever more lacking in dramatic potential. Erice's El sol del membrillo / The Quince Tree Sun (1992) follows this line in its focus on the supremely cinematic phenomenon of light transformed into time and time transformed into light; that is, the ungraspable ephemerality that Antonio López attempts to capture in his painting. Symptomatic in this respect is the interest in recent years in the documentary format. En construcción / Under Construction (José Luis Guerín, 2001) starts with the banner "Cosas vistas y oídas durante la construcción de un nuevo inmueble en 'el Chino,' un barrio popular de Barcelona que nace y muere con el siglo" (Things seen and heard during the construction of a new apartment block in the "Barrio Chino," a Barcelona working-class neighborhood born and dying with the century's end). This can be read as a manifesto of the film's working methods: its approach to observation and filming, editing and length of takes, acoustic match and mismatch. By patiently and persistently observing a historical enclave in the Catalan capital over three years, with the help of a team of students from the Universitat Pompeu Fabra's masters program in creative documentary, Guerín was able to offer a gaze that is the opposite of that of the news reporter: no sensationalist out-of-focus shots, no pans or rapid camera movements, no quick cutting or sense of urgency. On the contrary, carefully-thought-out long takes are employed, highlighting subtle contrasts (depth of field connecting the local inhabitants' everyday lives to the labor of the builders constructing the apartment block; passersby coinciding in the streets; posters, graffiti, or advertisements in the background). Sound follows the same rhythmic interactions: the voices are sometimes synchronous, sometimes out of sync; in some cases they are off-screen comments by passersby whose faces we do not see, but in other cases they appear on screen later. Image and sound are woven together freely. Nothing illustrates this so clearly as the sequence in which the drilling unearths some skeletons, which become the center of attention of the locals, the media, and experts alike - a veritable X-ray of the neighborhood. In this respect, Erice, Guerín, and Mercedes Álvarez (the editor of En construcción and director of El cielo gira / The Sky Turns (2004)) share a similar imaginative trajectory, an approach to reality grounded in documentary and fiction in equal doses.

A second - diametrically opposed - trend is that which packages together a series of attractions, as if returning to early cinema's origins in the fairground, albeit in blockbuster format. In this respect, the techniques of the video clip hyper-fragmentation and glossy design - play a major role. Juanma Bajo Ulloa's Airbag (1997) was presented as a provocative comedia gamberra; that is, a crazy comedy characterized by a rapid succession of events that mix the absurd, the iconoclastic, and the spectacular. This was followed two years later by Javier Fesser's El milagro de P. Tinto / The Miracle of P. Tinto (1998), a hilarious comedy with a somewhat more controlled visual imagination thanks to the meticulous photography of Javier Aguirresarobe. The editing created all manner of perceptual 
anomalies (extreme close-ups followed by establishing shots; high-speed hyperfragmentation; special effects, for which it won a Goya award). The fast-paced rhythm of such films suggests a resuscitation of the attractions that were cinema's principal selling point in its early days, with the entertainment sources that provide equivalent thrills today - the shopping mall, the slot machine, the computer game - reproducing their sensory regimes within the film as a succession of electric discharges. Torrente, el brazo tonto de la ley / Torrente, the Dumb Arm of the Law (Santiago Segura, 1998) and its sequels are eloquent examples of this modality.

In a context in which the editing and compositional conventions of the television series (shot/reverse shot, transitions via a theme tune, use of three-dimensional models for sets) and its styles of production design (glossy, impersonal, lacking signs of everyday wear and tear) are becoming standard, it is not surprising that a series of genre formulas, modeled on American cinema, are becoming codified, grounded in classical continuity editing but enriched with new sound technologies and the possibilities opened up by digital photography and digital editing. The potential of this kind of filmmaking is illustrated by Alejandro Amenábar, whose first film Tesis / Thesis (1996) drew on Hitchcockian suspense and the topic of snuff movies, and who skillfully exploited special effects in Abre los ojos / Open your Eyes (1997), which uses digital technology to enhance narrative artifice, and in The Others (2001), which at the same time draws on a US/British classic, The Innocents (Jack Clayton, 1961). Daniel Monzón’s Celda 211 / Cell 211 (2009) also draws on classical Hollywood cinema, productively exploring the genre of the prison movie, undeveloped in Spain. The return to the transparent conventions associated with genre cinema goes together with modest auteurist pretensions, through the development of a recognizable brand. If Aménabar incarnates this trend (see Chapter 5), films such as Barrio / The Neighborhood (Fernando León de Aranoa, 1998) illustrate a curious mix of realist observation with stylized auteurist traits. The credits draw our attention to the precariousness of the zoom lens, the limits of reportage, and the scope for technical imprecision with out-of-focus shots; nonetheless, the film is meticulous in its composition and editing, creating a kind of storyboard realism. This auteurist cinema has nothing to do with the grunge and lack of polish that gave the films of José Antonio de la Loma - such as Perros callejeros / Street Warriors (1977) - their vitality, as was also the case with the films of Eloy de la Iglesia from El pico / Overdose (1983) onward (see Chapter 6). The author's imprint imposes itself on reality, filters it, and aestheticizes it, turning it into an object of beauty.

\section{Conclusion}

The formal features that have made Spanish cinema what it is and the technical processes behind them (camerawork, production design, editing) have passed through the same stages of trial and error, hurdles, crises, and conflicts as has been 
the case with other national cinemas. The notion of the exceptionalism of Spanish cinema is not supported by evidence, unless by "anomaly" we just mean "cultural specificity." Cultural specificities there have been, as there are today: the highly idiosyncratic set designs of popular adaptations (of zarzuelas, of literary texts) in the 1920s; the enforced experimentation of the Civil War; the claustrophobic atmosphere of the postwar years; the prolongation of the studio age perhaps longer than in any other country; and the modest impact of lightweight cameras and direct sound in the modernizing phase that began in the late 1950s. But are these cultural specificities any greater than those represented by 1920 s German expressionism and Soviet montage, 1930s French poetic realism, the New York underground, or the cyclical recurrence of genres in Japan? A good case can be made for giving Spanish cinema back its normality; that is, its unsurprising singularity.

\section{References}

Eco, U. (1968) Apocalípticos e integrados. Barcelona: Lumen.

Fanés, F. (1982) Cifesa, la antorcha de los éxitos. Valencia: Institución Alfonso el Magnánimo. Fell, J. (1974) Film and the Narrative Tradition. Norman: University of Oklahoma Press.

Gorostiza, J. (1997) Directores artísticos del cine español. Madrid: Cátedra / Filmoteca Española.

Gunning, T. (1986) The Cinema of Attraction: Early Film, its Spectator, and the AvantGarde. Wide Angle 8 (3-4): 63-70.

Jameson, F. (1992) Postmodernism; or, the Cultural Logic of Late Capitalism. Durham: Duke University Press.

Lahoz, J. I. (ed.) (2010) A propósito de Cuesta. Escritos sobre cine español. 1896-1920. Valencia: Institut Valencià de l'Audiovisual i de la Cinematografia (IVAC).

López Clemente, J. (1989) Entrevista con Francisco Sempere. In: Llinás, F. (ed.) Directores de fotografía del cine español. Madrid: Filmoteca Española, pp. 347-53.

Medina, E. (2000). Cine negro y policíaco español de los años cincuenta. Barcelona: Laertes.

Palacio, M. (1997). Brigada criminal. In: Pérez Perucha, J. (ed.) Antología crítica del cine español 1906-1995. Madrid: Cátedra / Filmoteca Española, pp. 279-81.

Pérez Perucha, J. (ed.) (1982) El cinema de Edgar Neville. Valladolid: 27 Seminci.

Seguin, J.-C. (1997) Locura de amor. In: Pérez Perucha, J. (ed.) Antología crítica del cine español 1906-1995. Madrid: Cátedra / Filmoteca Española, pp. 230-2.

Sánchez-Biosca, V. (2010) El cine en la época de la Exposición Regional Valenciana. In: De la Calle, R. (ed.) El contexto artístico-cultural valenciano en torno a la Exposición Regional de 1909. Valencia: Real Academia de Bellas Artes de San Carlos, pp. 179-99.

\section{Further Reading}

Alarcón, E. (1984) El decorador en el cine. Torrejón de Ardoz: Festival de Cine de Alcalá de Henares.

Fernández Colorado, L. and Cerdán, J. (2007). Ricardo Urgoiti: Los trabajos y los días. Madrid: Filmoteca Española. 
García de Dueñas, J. and Gorostiza, J. (2001) Los estudios cinematográficos españoles. Special issue of Cuadernos de la Academia 10 (December).

Gorostiza, J. (2001) La arquitectura de los sueños: Entrevistas con directores artísticos del cine español. Alcalá de Henares: 31 Festival de Cine.

Heredero, C. F. (1993) Las huellas del tiempo: Cine español 1951-1961. Valencia: Filmoteca de la Generalitat Valenciana / Filmoteca Española.

Heredero, C. F. and Monterde, J. E. (2003) Los "nuevos cines" en España: Ilusiones y desencantos de los años sesenta. Valencia: Institut Valencià de l'Audiovisual i de la Cinematografia (IVAC).

Llinás, F. (ed.) (1989) Directores de fotografía del cine español. Madrid: Filmoteca Española. Sánchez Vidal, A. (1991) El cine de Florián Rey. Zaragoza: Caja de Ahorros de la Inmaculada. 


\section{Contents}

Acknowledgments viii

List of Figures $\quad$ ix

List of Contributors xviii

1 Introduction 1

Jo Labanyi and Tatjana Pavlović

$\begin{array}{lll}\text { Part I Reframing the National } & 13\end{array}$

2 Transnational Frameworks $\quad 15$

Gerard Dapena, Marvin D'Lugo, and Alberto Elena

Brad Epps

4 Negotiating the Local and the Global: Andalusia,

the Basque Country, and Galicia

José Colmeiro and Joseba Gabilondo

Part II The Construction of the Auteur

5 Auteurism and the Construction of the Canon 113 Marvin D'Lugo and Paul Julian Smith

6 Strategic Auteurism Antonio Lázaro-Reboll, Steven Marsh, Susan Martin-Márquez, and Santos Zunzunegui 
Part III Genre

7 Comedy and Musicals

Steven Marsh, Chris Perriam, Eva Woods Peiró, and Santos Zunzunegui

8 Melodrama and Historical Film

Jo Labanyi, Annabel Martín, and Vicente Rodríguez Ortega

Jo Labanyi, Antonio Lazaro-Reboll, and Vicente Rodriguez Ortega

\section{Part IV Stars as Cultural Icons}

10 The Construction of the Star System

Kathleen M. Vernon and Eva Woods Peiró

11 Stars, Modernity, and Celebrity Culture

Tatjana Pavlovic, Chris Perriam, and Nuria Triana Toribio

\section{Part V Image and Sound}

12 Photography, Production Design, and Editing

Vicente Sánchez-Biosca

13 Soundtrack

Romain Gubern and Kathleen M. Vernon

Part VI The Film Apparatus: Production, Infrastructure, and Audiences

14 Censorship, Film Studios, and Production Companies Josetxo Cerdán, Román Gubern, Jo Labanyi, Steven Marsh, Tatjana Pavlovic, and Nuria Triana Toribio

15 Film Clubs, Festivals, Archives, and Magazines Ferran Alberich, Román Gubern, and Vicente Sánchez-Biosca

16 Audiences Manuel Palacio and Kathleen M. Vernon

Part VII Relations with Other Media

17 Cinema, Popular Entertainment, Literature, and Television 
Part VIII Beyond the Fiction Film

18 Newsreels, Documentary, Experimental Film, Shorts, and Animation

Josetxo Cerdan and Vicente Sánchez-Biosca

\section{Part IX Reading Films through Theory}

19 Isabel Coixet's Engagement with Feminist Film Theory:

From $\mathrm{G}$ (the Gaze) to $\mathrm{H}$ (the Haptic)

Susan Martin-Márquez

20 Becoming a Queer (M)Other in/and/through Film:

Transsexuality, Trans-subjectivity, and Maternal

Relationality in Almodóvar's Todo sobre mi madre

Julian Daniel Gutiérrez-Albilla

21 The Space of the Vampire: Materiality and Disappearance in the Films of Iván Zulueta

Brad Epps

Index 